\title{
A Private Landowner Perspective of State Policy, Economics and Responsibility in Spruce Budworm Control ${ }^{1}$
}

\author{
by
}

\author{
Jerry R. Williams ${ }^{2}$
}

\begin{abstract}
International Paper Company owns 800000 acres of timberland in Maine stocked with spruce-fir that has experienced damage from the spruce budworm (Choristoneura fumiferana (Clemens)). Until 1982, these lands were included in the State of Maine-conducted aerial spray protection program. Following changes in state policy and administration, program costs, landowner objectives, and marketing requirements, IP withdrew from the state program to conduct its own program in 1983. Various economic and legal considerations with benefit/cost ratios from protection are described. In addition, the future wood supply is questioned and the state is encouraged to spin off the spray program to the private sector and to conceritrate its efforts on resource analysis, insect survey and detection and research.
\end{abstract}

\section{Résumé}

La compagnie International Paper (IP) est propriétaire de 800000 acres de boisés, dans l'État du Maine, pourvus d'épinette et de sapin, et endommagés par la tordeuse des bourgeons de l'épinette (Choristoneura fumiferana (Clemens)).

Ces forêts on été traitées jusqu'en 1982 en vertu du programme de l'État de protection par arrosage aérien. La compagnie IP a mis en place son propre programme de protection en 1983 suite à des modifications apportées à la politique du Maine ainsi qu'à des changements dans l'administration et les coûts du programme, dans les objectifs des propriétaires et dans les besoins du marché. Cet article présente plusieurs éléments d'ordre économique et légal, dont des ratios coût/bénéfice.

L'auteur met en questions la disponibilité de bois future et note qu'on encourage le gouvernement à laisser le secteur privé prendre charge de l'arrosage aérien, afin de pourvoir concentrer les efforts gouvernementaux sur l'analyse de la ressource, les relevés et la détection des zones d'infestation d'insectes, ainsi que la recherche.

\section{Company Background}

International Paper Company has been a corporate citizen in Maine since 1898, when the company was founded. Since then, International Paper has operated paper mills and managed timberlands throughout the state.

Most of the land ownership is in extreme northern Maine and has experienced infestations of the spruce budworm, (Choristoneura fumiferana (Clemens)), most recently during the World War I outbreak, the 1940s, the 1950s, and the present epidemic.

Current IP holdings in Maine include a paper mill in southwestern Maine which utilizes about 900 thousand cords annually, of which spruce and fir amount to one third of the

A paper presented at the International Forestry Congress held at Quebec City, Quebec, Canada on August 7,1984.

2Jerry R. Williams, Coordinator-Spruce Budworm Silviculture, International Paper Company, 9 Greene Street, Augusta, Maine 04330. furnish. Land management has divided responsibilities through two districts.

The Southern Maine District produces pulpwood from company fee lands for the IP Androscoggin Paper Mill in Jay, Maine. Although we do supply wood to our mill, about half of the harvest volume in this district is sold annually to outside markets. The Northern Maine District is located outside the economic transportation circle for the IP Androscoggin Mill. Thus, the timber harvested in northern Maine is sold to outside markets.

There is a very limited pulpwood market in our Northern Maine District and most of the timber is marketed as sawlogs or as chip and saw material. Because of the high percentage of spruce-fir sites and stocking in the Northern Maine District, this is where IP is most vulnerable to the spruce budworm.

Approximately $35 \%$ of our northern Maine lands are economically vulnerable to the spruce budworm. Our definition for 
economic vulnerability is the probabiity that damage, in terms of tree growth and mortality, will result from budworm attacks and reduce the expected financial return from the present high value, mature stands at harvest time.

Our total forested area is about 1 million acres, of which $80 \%$ is comprised of softwood and mixwood types, containing spruce and fir at various stocking levels.

\section{Spray Policy}

During the mid-1950s, when it became necessary to spray small portions of timberland in northern Maine with DDT to reduce budworm populations and damage, the Maine Forest Service identified the location and severity of outbreaks and designated the control area. These control areas were treated by a Maine Forest Service-conducted program. Funding was to be from three sources - federal, state general funds, and a tax to the landowners based on their proportionate share of the timberlands owned in the Maine Forest District (i.e., timberlands in the unorganized townships or so-called wildlands).

The major landowners agreed to share the cost and recognized that by taxing proportionate to ownership in the MFD, the yearly tax burden would be reduced for landowners and that the protection would provide benefit to other landowners as well. This policy continued through the mid-seventies.

When the epidemic "exploded" in 1974, the state began to review its role and policy in budworm protection programs. It immediately reduced its contribution from the General Fund, leaving the balance to be raised from the landowners and federal grants. The state then instituted a new program to run from 1976 to 1981 . The new program as mandated by the Legislature was known as the 1976 Budworm Suppression Act and the mandate was specific, "To protect and preserve the spruce-fir forest resources of the State of Maine from the ravages of spruce budworm infestation." The Act also contained a basic objective to accomplish, "The maximum sustained yield harvest possible within a Maine forest comprised of the most valuable timber possible. ..." This required that the Maine Forest Service resort to the only tool available at that time for preventing widespread tree mortality - chemical insecticide spraying.

The Act also contained provisions for promoting the development of a spruce-fir forest that is less likely to support high budworm populations and suffer damage from future outbreaks. However the Maine Forest Sevice responsibility for dealing with the budworm problem did not necessarily require that the state administer the spray operation. It then became the goal of the Maine Forest Service and the Department of Conservation to spin off the operational aspects of spraying to the private sector and it expected to accomplish this goal not later than 1981. During this period, the state developed a formula for cost sharing based on stumpage values, tax revenue losses, and fire fighting costs attributable to budworm damage.

Another benefit/cost evaluation for the proposed 1976 suppression project by the Maine Forest Service identified other socio-economic values, such as a projected payroll loss of $6.4: 1$. In the 1977 project, $16 \%$ of IP acres designated for protection by the state were within water or deer wintering area zones where harvesting was strictly limited by volume removal and cycle by the State Land Use Regulation Com- mission. However, the state policy was to disregard the socioeconomic values in cost sharing and to consider primarily the stumpage value to the landowner.

In 1977, the control program was financed as follows: federal contribution - 36\%; General Fund - 2.5\%; and budworm excise tax $-61.5 \%$ from owners of taxable parcels of land in the spruce fir protection district.

The Spruce-fir Protection District represented primarily the unorganized townships that comprise the old Maine Forest District. The excise tax was still based on the landowners pro-rata share within the Spruce-fir Protection District. The Maine Forest Service entomological staff would conduct surveys culminating in a report of present conditions and recommendations including the designation of the next year's control program.

Early in the epidemic, the landowners looked to the state for a spray recommendation, as little was known about the budworm interaction in the high population levels of the mid$70 \mathrm{~s}$. But as the years went on, the landowners continued to request that the recommended spray area be reduced through better targeting of areas to receive treatment. Throughout this period, part of the public was concerned that the state should not be involved in the spray programs and should not be contributing to their cost from the General Fund.

In 1980, the landowners supported a state policy change in which the landowners' cost would be changed from a simple proportionate share of the SFPD to a formula putting more of the tax burden on those landowners receiving the spray benefit. It was also recognized through studies and task groups and with a request of landowners that the State should continue to administer the spray protection program. A new statute was enacted in 1981 to become effective for the 1982 program.

This program, which is still in effect, became a volunteer program by the landowners if they wanted to participate, with the landowners identifying the areas to be treated. The state would continue to provide the entomological survey data and research, as well as conduct the application program. The cost would be shared by the landowners and, if grants were approved, by the federal government; the state would not contribute directly to the suppression program.

The landowners' share of the non-federal contribution would be $90 \%$ paid by the landowners through a spray tax to the landowners receiving the benefit. The remaining $10 \%$ of the program cost would be based on the landowners' proportionate share of a volunteer spruce-fir protection district. The state would be contributing indirectly by providing support services paid through the General Fund. This policy is still in effect, except that the state has reduced most of its indirect financial support by not funding portions of the support services which has increased the project costs paid by the landowners. The federal government also has not contributed to the spray project since the 1982 program.

\section{What is the Impact on IP of the Spruce Budworm Epidemic}

Prior to 1974 , most of our spruce-fir harvests were partial cuts on a 20-30 year cycle, and primarily individual tree selection. Residual stands contained a higher ratio of spruce stocking than fir, were relatively wind firm and contained a mixed age class. Once the budworm outbreak exploded and dam- 
age was visible, we initially shifted harvest and road building activities to the high hazard areas. As we increased our discrimination against fir by continuing to favor spruce and retaining even fewer fir in our residual stands, we soon realized that the damaged stands were more susceptible to wind breakage and windfall than in our previous harvest areas. It became necessary to change our harvesting method. We then began prescribing clearcutting for stands of heavy fir stocking and by-passing many stands with $60 \%$ or more spruce stocking.

Because we were shipping pulpwood or chips material to our paper mill in southern Maine by rail from northern Maine at the onset of the epidemic, we were bullish on spray protection to protect a needed fibre supply for our mill as well as to reduce value loss through mortality.

However, by 1980 , our marketing conditions changed. Increasing freight rates made it unattractive to ship wood from northern Maine to our mill. During this same period, the Maine Forest Service decided to withdraw protection permanently from 800000 acres in central and western Maine. This led us to increase our salvage areas in these sections while other landowners, including small landowners, were also increasing their salvage and premortality salvage operations.

Because we no longer had a need in northern Maine to protect a long-term fibre supply for our mills, we dramatically increased our salvage/presalvage efforts there. This increase in harvest volume, primarily coming from severely damaged budworm stands, allows us to recapture significant volume of budworm mortality and reduces our reliance on spray protection. Our statewide harvest volume of spruce-fir increased by $50 \%$ to an annual harvest volume of nearly a $1 / 2$ million cords.

Our papermill complex at Jay, Maine and supporting capital projects represent nearly a $1 / 2$-billion-dollar investment by IP during the past 20 years. We recognized that because of increases in local harvesting and budworm mortality, the age class structure of the forest would change and the future harvest of spruce-fir would fall by the year 2000. To protect our high investment in the mill, we began a redeployment of our land base. We have acquired nearly 200000 acres of timberlands in the truckwood zone and have sold a similar size unit located in northern Maine.

Currently, our silvicultural control techniques are principally harvest related, but we have done some operational research and field trials and where economically justified, operational implementation in site preparation, planting, fir reduction (down to $1^{\prime \prime} \mathrm{dbh}$ ), brush saw spacing, and herbicides. These silvicultural techniques follow the suggestions as outlined by Batzer (1974) in his review of the literature for a 50 -year-period and restated more recently, with some variation, by Montgomery et al (1982).

Additionally, we have had to bear the financial cost of aerial spray protection and management costs. This cost ranges from a high in 1980 of $1 \frac{1 / 4}{4}$ million dollars to our present cost of slightly more than $1 / 2$ million dollars. This reflects an annual outlay of nearly $\$ 1.00$ per acre, for each acre in our Northern Maine District. The increased financial costs due to the budworm for the past decade have reduced the cash flow available for other investments in forest management.

The project costs for the budworm program have risen from $\$ 2.43 /$ acre in 1976 to $\$ 10.35 /$ acre in 1982 . The increase has not been a straight line change as the program cost in
1979 rose to $\$ 3.87$ /acre; by 1980 , it jumped to $\$ 6.09$ /acre, increased only slightly to $\$ 6.17$ / acre in 1981 , but dramatically jumped to over $\$ 10.00 /$ acre in 1982 . In 1983 International Paper conducted its own spray treatment program and our costs dropped below $\$ 5.00$ /acre which was slightly above the 1979 State program cost, and our cost has remained basically the same for the 1984 program.

\section{Difficulties Encountered in Being Part of the State of Maine Protection Program}

Because of the size of a single state program operating from four or more airports and providing protection for many landowners, many of whom had different goals, contending with the state program became a bureaucratic nightmare.

First, the state required that a landowner request spray protection for areas by December 1, preceding the spray treatment. The landowner would then have until February 1 , to withdraw any areas, but could not add or substitute acreage. IP had changed its marketing program resulting in no wood being shipped to Company mills from our Northern Maine District. Because of this decision, we were relocating many woods operations. Additionally, the lumber market was in a severe decline and we found it necessary to switch or modify harvesting plans to take advantage of all existing markets that we could find. We found the State policy too inflexible under such dynamic conditions.

Second, with a large program and a multitude of landowners being served, there is always some land treated early in the program and other lands treated late. However, in one program, over $2 / 3$ of our spray areas were treated in the last $2 \frac{1}{2}$ days of a program which had run over 20 days. We did not receive satisfactory treatment as considerable defoliation had occurred before the treatment. During the program, it often became necessary for the state to drop areas and frequently the landowner was not provided a fair opportunity for input to allow the best decision to be made based on the biologic conditions of the host and insect, and the landowner's objectives.

In dealing with the state, we often found managers or program leaders difficult to contact, unresponsive to requests, and all too frequently, unable to make timely decisions. This made it hard for us to make business decisions and conduct forest management activity planning.

We viewed the state's program as containing excessive full time personnel and support equipment. We also believe that the state lost control of cost accounting and accountability. For example, the state program received legislative approval for a project estimated to cost less than $\$ 8.00 /$ acre in 1982 and they allowed cost overruns to bring the project to $\$ 10.35 /$ acre. This overrun occurred in less than six months from receiving legislative approval. Landowner representatives cautioned the state during the project contracting period that the costs were becoming excessive, but the Maine Forest Service disregarded landowner input. This additional cost had to be paid in the 1982 calendar year as a tax by the landowner. The resulting excise tax increase caused IP, at mid-year, to withdraw funding for other forest management activities.

During 1981 and mid-1982, International Paper explored the feasibility of withdrawing from the state's program and providing its own protection. Although we recognized the benefits to be achieved through better efficiencies and a more flexible program, we believed the state could improve its oper- 
ations and decided to remain in the state's program. By the fall of 1982 , the state had been without a permanently assigned Forest Insect Manager to plan and supervise the state program for nearly a year. Apparently the position would not be filled in time to effect improvement in the 1983 program. Because of the rigidity of state policy and apparent lack of leadership and because the state's costs were out of control (i.e. 1982 project cost), IP decided to conduct its own spruce budworm spray program for 1983.

The decision to withdraw from the state program did not come easy. In the past, International Paper strongly supported all policies that would have the state conduct the spray applications and we were opposed to any spin-off to the private sector. Let me share with you a quotation from John Walker when he was director of the Maine Forest Service to the Bangor Rotary Club in 1978:

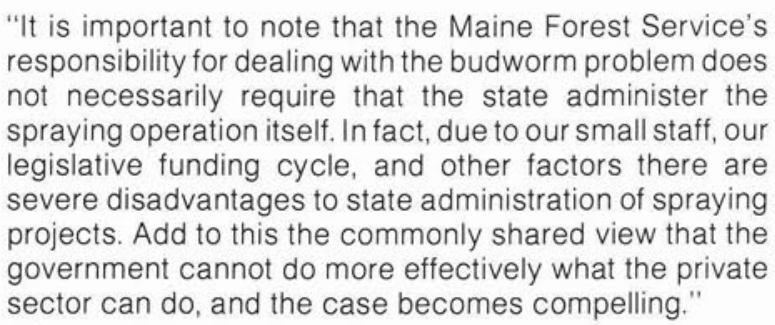

Although we recognized the reasons that the state should not be doing the spraying were realistic, we believed that the state could improve its program and would provide cost-effective protection. However, in retrospect we now find that what Walker said was all too true.

\section{The Decision to Conduct a Private Spray Program by IP}

There had been much talk in Maine about the consequences any private entity faces in undertaking its own spray project. Much of the opposition was based on emotionalism and not on fact. The record of the state program was good in minimizing the threat to human health and the environment. This is not to say that there were no problems, but that through planning and controls in the application phase and selection of insecticides, the risks were kept to an acceptable level. We believed that there may be some liability protection to a landowner under the blanket of a state-conducted program, but because of the involvement of the landowners in identifying and requesting areas to be sprayed, the landowner was in a perilous position relating to liability.

International Paper Company has a chemical use policy and I would like to quote the first two paragraphs of that which set the scope of the direction that we had to follow in designing any spray program.

\begin{abstract}
"IP's land management policy is to protect its forest from insects, disease and rodents as well as encroachment by plants of undesirable weed species. In administering this policy, the safety of company employees and the public is the top priority.
\end{abstract}

Silvicultural chemical are only part of the total management package to be used to protect and improve the productivity of IP's forestt resources. When the most effective choice - economically and technically - for forest management requires the use of a chemical, then IP managers and employees have the responsibility to ensure that the selection, handling, storage and application of the chemical are done properly."

After several meetings with IP's corporate legal staff, outside counsel, and IP regional forestry staff, it was decided that a program could be conducted only if it met certain quality points established during that review and could be economically justified. We believed that a well-planned and executed program, designated through quality control and contract specifications to minimize risk to human health and the environment, would likely avoid the costs of expensive litigation. We would require, as any prudent business would, that the applicator carry chemical liability insurance. However, we did not feel the amount was excessive and we ensured that our contract included clear specifications based on the applicable laws and regulations and technological knowledge to ensure a safe program. We agreed to have a contract compliance person in the monitor aircraft who has the authority to shut down the operation at any time he believed that irregularities were present.

\section{IP Aerial Spray Program}

We then treated 100000 acres using chemical and biological insecticides. Using biological insecticides in that area in conjunction with chemical insecticides was a new tactic. Because of the area's remoteness and the necessity of the state to truck its materials over 100 miles to the airstrip from the mixing site, an integrated use of chemical and biological insecticides was not achieved prior to our program. We believed that the use of the biological insecticide (Bacillus thuringiensis, $\mathrm{Bt}$ ) would be effective and worth the greater cost for the material because it is recognized to be non-toxic to humans and safe in the environment.

Bt was used to treat environmentally sensitive areas as well as those areas where we felt there would be human exposure during the spray treatment period. The state guidelines restrict chemical spraying adjacent to water. IP voluntarily increased the size of buffers along water courses for its chemical treatment program and treated these areas with $\mathrm{Bt}$, if treatment was warranted. Bt comprised $35 \%$ of the IP program.

One way to reduce the public emotionalism toward the budworm program is to ensure that everyone visiting or traveling near a spray block be informed as to block location, insecticides being used, timing, and detailed product information.

Most of our treatment area in 1983 and all in 1984 was within an area with tightly controlled road access. At 11 road control checkpoints, the only authorized access into the spray treatment areas, spray notices were posted and maps with written advisory information were provided to every vehicle driver. Product information booklets and a large map atlas identifying the spray areas and road systems were available for public examination. In addition, we required the driver and occupants of any vehicle traveling into a spray area to sign a waiver stating that they had been informed of the spray activities. This is a more extensive notification prosedure than used in the state's program. In addition, within the property at major road intersections and spray boundaries or other significant points, posters were maintained throughout the program. Side roads that lead into chemical spray areas and where unauthorized camping was expected were temporarily closed to the public. During the spray period, major access roads were 
closed by manned road blocks to prevent inadvertant application to people travelling through a spray block.

IP contracted the storage, mixing, loading, and application of insecticide to an experienced licensed applicator. Manufacturers' product specialists were on site to advise and inspect the activities related to their product. The product specialists also assisted in calibration of application systems. Chemical insecticides were received and stored in bulk tankers and were loaded into planes through closed pumping systems with appropriate safety bypasses. All areas were preflown by the spotter, contract compliance officer and guide pilot to ensure that all knew exactly the targets to be sprayed. To ensure contract compliance was maintained and correct application to intended targets, we selected for our contract compliance person a forester with a pesticide applicator license, with over 20 years field experience in the area being sprayed and who was knowledgeable of the target boundaries and their identification. We also monitored the application through the use of spray deposit cards and water sampling. Analysis of the cards and water samples indicated that no spray material entered the waters at the monitoring sites. In addition, a chemical supplier's water monitoring achieved the same results. The State Bureau of Pesticide Control had two inspectors monitoring our program who took water samples at other locations. Following the project, they concluded that our program was safely conducted. Our 1984 project was similarly conducted, but with Bt usage increased from $35 \%$ in 1983 to $48 \%$ in 1984 .

\section{What has IP Gained from Conducting Its Own Program}

We have gained efficiencies in our program through not having to assign personnel to develop information for a state program or to monitor the state's program as closely as we had previously. Our program has been more flexible allowing us to make changes as field conditions and management decisions have changed.

Our protection results in 1983 were equal to the state's for spruce and slightly better on fir due to the differences in timing of applications. In 1984, we expect that efficiencies in our program will lead to IP saving more than $\$ 300,000$ compared with the state's program. This amount of savings is important and could be much greater if IP elected to meet only the minimum requirements for applications. However, to achieve a high quality and safe program, we believe that our extra costs are justified and are willing to accept them.

\section{Wood Supply}

In 1984, the Maine Forest Service released the study of Wood Supply and Demand Analysis. This was based on input from various mill owners and the US Forest Service reinventory of the state timber resource. It is too early for me to make an evaluation of the study's projections. There are many assumptions that one may question and perhaps some assumptions that are missing. Currently, we are harvesting more spruce and fir than 10-15 years ago. This high level of fibre availability resulting from salvage and a concentrated effort to reduce vulnerability by getting to the resource before the bug does is expected to last for several years. Looking back, we find that following the World War I epidemic and a salvage period extending into the late 1920 s, much of the area regenerated and did not reach merchantable size until the late 1960 s or early 1970s. Because of low demand, the available spruce and fir undamaged by budworm met market needs.
The era of establishment of new mills or expansions to utilize the spruce-fir rotation that followed the World War I epidemic began in the mid-60s and continued to the late $70 \mathrm{~s}$. I would expect the same trend to follow this epidemic but to a lesser degree. Spray intervention should lenghten the period of salvage and silvicultural treatments, such as planting faster growing species, thinning and use of herbicides, may reduce the waiting time for stands to reach operational size.

For many years, the supply of spruce-fir relative to demand has been abudnant. We are expecting this to change and a future timber shortage. Timber shortage as defined by Field (1980) is, "That there exists less timber, of some species, size, and quality class, in a given area, within a given time interval, than the amount that would be needed to satisfy some human desire at a given price." Field goes on to state that, "There is no reason why Maine has to grow enough timber to meet all of the present and future demands placed on its land resource. The question is the human one of economic opportunity, and the ability to take advantage of that opportunity." This is something to ponder.

Mills and landowners will face challenges in a reduction of spruce fibre availability. Some mills will be able to shift to other species, some mills may close for a variety of reasons, i.e., age, high production costs, fire, etc., which will reduce the demand. Landowners may be able to increase the supply through better utilization and silviculture. The question of wood supply is perceived somewhat differently by users, landowners and government planners, and I do not believe we have a clear picture of the future.

\section{Economics of Spray Protection}

A review of timber stand conditions in earlier Maine spray programs and in New Brunswick clearly showed that spraying has been effective in preserving foliage and reducing tree mortality over the large treated areas (Irland 1977). But we found there was insufficient data about the long-term effects on growth of surviving trees and prevention of mortality to complete a true economic analysis. For the short-term, the alternative to spraying was to do nothing and accept losses, or to reschedule cuttings to maximize salvage of damaged timber. As mentioned earlier, we did embark on a more bullish salvage-premortality salvage program to recover as much stumpage income as possible and to reduce spray protection costs. We also identified areas that were so severely damaged or were so inaccessible that it was not feasible to salvage them. These areas were abandoned and, as expected, the forest has died with no realization to the company from fibre or income.

There has been a multitude of calculations regarding the economic benefit of spray protection in Maine. An early report in 1976 by the Maine Department of Conservation entitled "Appendix B, Benefit/Cost Evaluation for Proposed 1976 Maine Spruce Budworm Project'" indicates cost benefits ranging from 3.06:1 to $6.91: 1$ for the area of our operations. The benefit/cost ratio essentially expressed the benefit or return for each dollar of cost expended. Income considered was only the stumpage value. The above analysis was done using a discount rate of $10 \%$ and was for a 60 -year rotation and assumed a sustained yield of harvest volume.

We looked at this approach and felt that it did not accurately reflect the benefits for IP's lands being treated. Our lands being treated support mature stands and are those of the higher stockings and value. During the late 70 s we esti- 
mated that the stumpage value of our stands being protected was worth approximately $\$ 250$ an acre and that the annual protection cost was approximately $\$ .35$ per cord. This, in our opinion, was a very acceptable short-term cost and would allow us to harvest stands in a 10-15 year period.

For benefit/cost analysis, we use current year costs and stumpage value without an inflation escalation, a six \% discount factor and our own resource information. The benefit to cost ratio is the present value of benefits compared with the present value of costs.

A study of our growth plot information comparing our untreated areas with treated areas indicates that survivor and ingrowth volumes are at least $42 \%$ greater in areas where protection has been infrequent to a doubling of growth in areas where protection has been relatively consistent and sprayed the equivalent of every other year. The value of this growth seems to be the same as our spray protection cost on an annual basis, and as spray protection is estimated to be accomplished bi-annually, the benefit cost is 1.7:1.

Some early studies of the treatment areas, involving company management objectives and assumptions indicate benefit/cost ranging from $4: 1$ to $7: 1$ for a short-term, 15-year period.

We still are not satisfied with the economic studies and are continuing to review and complete new analyses. Later this year, we shall have complete coverage of 1984 color infra red photography for our Northern Maine District and will redefine our forest condition. In 1985, we shall have new data from our CFI program. We expect to redo our benefit/cost analysis using new resource and forest conditions data with growth/ yield data from research and monitoring studies.

\section{What Should the State Policy Be?}

There has been a proliferation of private budworm spray programs in Maine. In 1983, there were six private projects outside the state program. In 1984, it is estimated that more than one-quarter of the statewide treated acres was accomplished outside the state program. IP believes that the time has come for the State of Maine to spin off the application to the private sector. Successful completion of several projects demonstrates that the private sector is able to safely conduct efficacious, and we believe more cost-effective, application programs. The State Bureau of Pesticide Control has grown in size and experience and should be the regulating and monitoring agency. The Maine Forest Service should retain the survey and detection activities, research involving new insecticide formulations, insect and host studies relative to treatment/non-treatment strategies, and more aggressively surveying the timber resources. The private sector and the two state agencies we believe can work cooperatively in dealing with the budworm.

\section{References}

Batzer, H.O. 1974. Silvicultural control techniques for the spruce budworm. Proc. of a Symposium on the Spruce Budworm. USDA For. Serv. Misc. Pub. No. 1327: 110-116.

Fleld, D.A., 1980. The economic importance of Maine's spruce-fir resource. School of Forest Resource, Life Sciences and Agri. Exp. Sta. Univ. Maine. Misc. Rep. No. 227, 34 p.

Irland, L.E., 1977. School of Forest Resources, Univ. Maine, Tech. Note No. 67, 26 p.

Montgomery, B.A., J.A. Witter, G.A. Simmons, and R.G. Rogan. 1982. The spruce budworm manual for the Lake States. Michigan Co-op Forest Pest Management Program Tech. Man. 82$6 ; 49-54$.

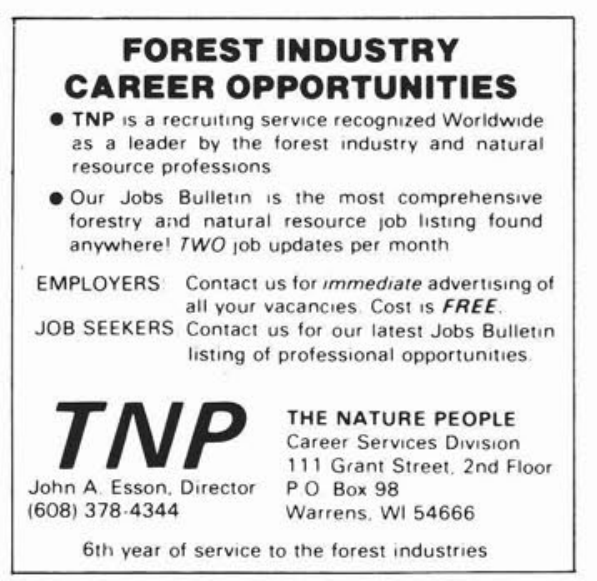




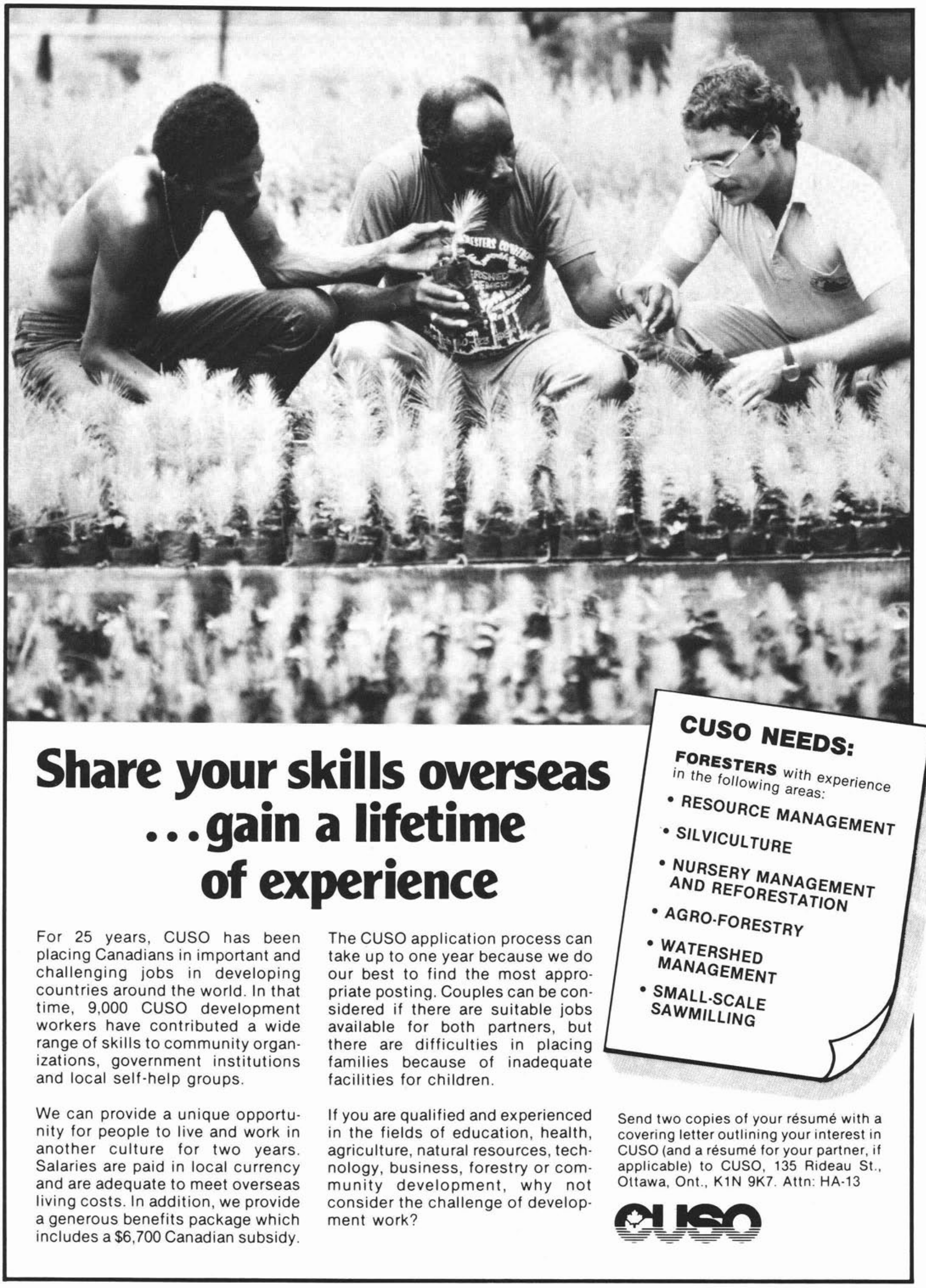

